\title{
Milk composition of Pakistani camel (Camelus dromedaries) kept under station/farmer's conditions
}

\author{
A. Iqbal", R. A. Gill and M. Younas
}

Department of Livestock Management, University of Agriculture Faisalabad-38040, Pakistan

\begin{abstract}
A six month study involving milk samples from 14 freshly calved she-camels was undertaken at Barani Livestock Production Research Institute (BLPRI), Kherimurat, District Attock (Punjab-Pakistan). These animals were maintained on vegetation mainly comprised Pholai (Acacia modesta) Kandair (Alhaji camelorum) and Kahu (Olea ferruginea). Representative milk samples from experimental animals were collected on monthly basis and analysed for various milk constituents by standard methods. Average percentage values of protein, fat, solids-not-fat (SNF), total solids(TS) and titratable acidity (TA) in milk were $2.85 \pm 0.036 ; 3.57 \pm 0.09 ; 9.00 \pm 0.13 ; 12.36 \pm$ 0.19 and $0.20 \pm 0.005$, respectively. Fat percentage was found lower than that of many cattle breeds. Moreover mean specific gravity of camel milk was $1.03 \pm 0.007$. On overall basis, average milk composition observed during the first month of lactation in the present study remained almost constant for the first six month. Results of the present study contributed to the nutritive quality of camel milk and overall knowledge of this animal species as a food source for an overpopulated and underdeveloped country like Pakistan.
\end{abstract}

Key words: milk, lactation, camel, Pakistan.

* Corresponding Author.

\section{Introduction}

Globally there are 19.5 million camels (both Camelus dromedarius and Camelus bactrianus). Pakistan ranks at $5^{\text {th }}$ position with 0.9 million heads of camel (FAO, 1997). These animals are primarily used for draught purpose and with less importance for milk and meat in different areas of Pakistan. The milk production potential of Pakistani camel is well recognized in the world. Their milk production ability is evident from the fact that they can produce up to 12000 liters in a lactation period ranging from 9 to 18 months (Schwartz, 1992). Camel is still unrivalled in its ability to utilize the desert and steppe regions of the world for the production of milk, meat, wool, etc. Moreover, camel can thrive under extreme hostile conditions of temperature, drought and lack of pasture and still produce milk of high nutritional quality (Yagil and Etzion, 1980). Despite possessing the aforesaid characteristics, camel remained the most neglected animal species in the country due to lack of organized research endeavors. Although the data on few aspects of chemical composition of camel milk has been reported by several workers (Yagil, 1982; El-Amin and Wilcox, 1992; Khanna and Rai, 1993) with a wide variation in its constituents but no scientific study has undertaken on the gross composition of camel in Pakistan, hence the present study was planned. The objective of this study was to study milk composition of Pakistani camels.

\section{Materials and Methods}

Fourteen freshly calved she-camels (five belonging to BLPRI and nine from surroundings of BLPRI) having almost similar body weight and lactation number were considered. Immediately after milking, the milk was mixed well and fresh composite samples of milk were taken on monthly basis during the first six months period postpartum to analyse them for the determination of percentage of fat, protein, acidity, specific gravity (David, 1977) besides total solids (TS) and solids-not-fat (SNF) as described by Eckles et al. (1982). The institute owned lactating animals were watered twice a day (morning and evening) before leaving for browsing/grazing in the morning and then on their return to their 
premises in the evening. Animals were kept entirely on browsing/grazing during day time. Ad libitum salt was made available in their yard. The privately owned she-camels were raised according to their traditional husbandry practices. The collected data were subjected to statistical analysis and various descriptive statistics (means and standard deviation) were calculated following the procedures described by Sokal and Rohlf (1995).

\section{Results and Discussion}

Average milk composition observed during the first month of lactation in the present study remained constant for the first six months (Yagil, 1982). Generally camel milk is reported to be variable in its composition owing to the greater variety in its diet and is similar to cow milk (Yagil and Etzion, 1980). Monthly milk composition of the experimental animals is giving in Table 1.

Acidity in milk mainly reflects temperature of milk after collection, husbandry techniques and marketing practices. The average acidity of the milk worked out to be $0.20 \pm 0.005 \%$ with a range of 0.19 to 0.20 $\%$. The results of the present study are in consonance with the results of El-Erian, $1979(0.11$ to $0.21 \%)$. The titratable acidity in the present study was found higher in comparison to that of acidity noted in camels of Saudi Arabia by Sawaya et al. (1984). These values are also higher than those of cow milk.

On overall basis, the value of specific gravity was found to be $1.029 \pm 0.007$, ranging from 1.028 to 1.033 , which is lower than that of cow, buffalo or sheep milk. These results are almost in agreement with the findigns of Karim and Gooklani (1987), Khanna and Rai (1993) and Mohamed (1993). Mean value of protein was found to be $2.85 \pm 0.036 \%$, ranging from 2.84 to $2.98 \%$. These results are in agreement with those of Abu-Lehia (1987) and El-Amin and Wilcox (1992). Knoess (1977) and ElAmin (1979) both reported higher values for Adal and Sudanese camel milks (4.5\% and $4.7 \%$ respectively).

Average value of fat in camel milk was $3.57 \pm 0.091 \%$, ranging from 3.47 to 3.68 $\%$, which is comparable to the cow milk. Fat percentage in this study agrees with the value (3.60) reported by Sawaya et al. (1984). Generally, estimates of fat percentage of camel milk vary with the season (Knoess, 1986), stage of lactation (El-Amin, 1979; Zia-ur-Rehman, 1998) and milking frequency (Rodriguez et al, 1985). However, contrary to these factors Knoess et al. (1986) observed that average fat percentage did not depend on the stage of lactation but more likely on the climate and probably on the air temperature.

Table 1. Composition of camel milk during first six months of lactation

\begin{tabular}{lcclccc}
\hline \multirow{2}{*}{ Month } & \multirow{2}{*}{$\begin{array}{c}\text { A) } \\
\text { Acidity }\end{array}$} & $\begin{array}{c}\text { Specific } \\
\text { gravity }\end{array}$ & \multicolumn{1}{c}{ Protein } & \multicolumn{1}{c}{ Fat } & \multicolumn{1}{c}{ TS } & SNF \\
\hline 1 & $0.20 \pm 0.008$ & $1.032 \pm 0.0009$ & $2.91 \pm 0.078$ & $3.47 \pm 0.148$ & $12.5 \pm 0.31$ & $9.18 \pm 0.22$ \\
2 & $0.19 \pm 0.008$ & $1.031 \pm 0.008$ & $2.80 \pm 0.06$ & $3.58 \pm 0.16$ & $12.38 \pm 0.29$ & $8.82 \pm 0.27$ \\
3 & $0.21 \pm 0.009$ & $1.030 \pm 0.0008$ & $2.64 \pm 0.085$ & $3.54 \pm 0.13$ & $12.22 \pm 0.23$ & $8.67 \pm 0.213$ \\
4 & $0.19 \pm 0.005$ & $1.032 \pm 0.007$ & $2.86 \pm 0.063$ & $3.58 \pm 0.13$ & $12.59 \pm 0.29$ & $8.93 \pm 0.25$ \\
5 & $0.20 \pm 0.005$ & $1.030 \pm 0.006$ & $2.98 \pm 0.08$ & $3.68 \pm 0.14$ & $12.28 \pm 0.3$ & $8.57 \pm 0.34$ \\
6 & $0.20 \pm 0.005$ & $1.029 \pm 0.0009$ & $2.96 \pm 0.06$ & $3.51 \pm 0.096$ & $11.89 \pm 0.28$ & $8.35 \pm 0.27$ \\
\hline
\end{tabular}


It was reported that during the hot months (April to September), the fat percentage dropped to 2.9 to 2.6, while in cold months fat percentage increased irrespective of the stage (start or end) of lactation. This is in accordance with the high water requirements of the calf in extreme hot months. Yagil and Etzion (1980) reported that high temperature and water restriction increased the water contents in camel milk and reduced its fat percentage.

Percentage of total solids on an average was found to be $12.36 \pm 0.192$ ranging from 12.22 to 12.59 . Almost similar findings have been reported by Mohamed (1993). Khanna (1986) is of the opinion that total solids in camel milk are comparable to cow milk, higher than goat, mare, and woman milk but lower than those of buffalo and ewe. Hassan et al. (1987) and El-Amin and Wilcox (1992) reported lower total solids $(10.95 \%)$ in milk of Majaheem and Egyptian (10.90 \%) camels respectively. Similarly, Desel et al. (1982) also found a lower total solids content $(9.80 \%)$ as compared to the present study.

Mean values of solids-not-fat (SNF) contents were $9.00 \pm 0.13 \%$, ranging from 8.35 to $9.18 \%$. These results were comparable with those given by Khanna and Rai (1993) i.e. 8.9 to $14.3 \%$ and Mohamed (1993) i.e. $8.4 \%$. Contrary to the present results Harbans (1962) reported $10.1 \%$ SNF, which are a bit higher than the values found in the present study, whereas lower values (6.1 and $7.4 \%$ ) were reported by Desel et al. (1982) and Hassan et al. (1987), respectively.

The differences in solids-not-fat contents could be attributed to season (Eckles et al., 1982), quantity/quality of feed (Rakes and Stallcup, 1975) and variation due to breed and species differences (Tilakaratne et al, 1975).

\section{Conclusion}

The results of the present study idicated that camelmilk has a good nutritive quality and can be a good source of nutrients in human diet in the arid and semiarid zones. A lot of information are still to be generated about camel's milk as a source of food. In this context, research can be focused to investigate its certain aspects like therapeutic value or the impact of different husbandry systems on its quantity and quality.

\section{Acknowledgements}

The authors are grateful to ACSAD (Syria) for financial assistance and the Directorate of Barani Livestock Production Research Institute (BLPRI) Kherimurat (Punjab-Pakistan) including the private farmers owning camels surroundings this institute for providing their lactating shecamels during the study.

\section{References}

Abu-Lehia, I. H. 1987. Composition of camel milk. Milchwissenschaft, 42(6): 368-371.

David, C. L. 1977. Laboratory Guide in Dairy Chemistry Practicals. FAO Regional Dairy Development and Training Centre for Asia and Pacific. Dairy Training and Research Institute, University of Philippines, Loss Banos College, Laguna, Philippines.

Desel, H. K., J. N. Patel and A. J. Pandya. 1982. Composition of camel's milk. Gujrat Agri. Univ. Res. J. 2:131-132.

Eckles, C. H., W. B. Combs and H. Macy. 1982. Milk and Milk Products. McGraw Hill Book Co. Inc., New York, USA.

El-Amin, F. M. 1979. The dromedary camel of the Sudan. In: Proc. Workshop on Camels. 18-20 December, Khartoum, Sudan:35-54.

El-Amin, F. M. and C. J. Wilcox. 1992. Milk composition of Majaheem camels. J. Dairy Sci. 75:3155-3157.

El-Erian, A. F. M. 1979. Studies on camel milk in the Kingdom of Saudi Arabia. 
Proc. 2nd Arab Conf. Food. Sci. Technol:125-134.

FAO. 1997. Production Year Book. 51:192194, Rome, Italy.

Harbans S. A. 1962. Handbook of Animal Husbandry for Extension Workers. Ministry of Food and Agriculture, New Delhi, India.

Hassan, A. A., A. E. Hagrass, K. A. Soryal and S.A. El-Shabrawy. 1987. Physicochemical properties of camel milk and duration of lactation period in Egypt. Egyptian J. Food Sci. 15(1): 1-14.

Karim, G. and I. Gooklani. 1987. Studies on the gross components of camel milk in Turkman Sahara. J. Vet. Faculty, Tehran, Iran, 42(1): 26-28.

Khanna, N. D. 1986. Camel as a milch animal. Indian Farming, 36(5)37:39-40.

Khanna, N. D. and A. K. Rai. 1993. Milk production potential of Indian Camel. Asian Livestock, 18(1):19-21.

Knoess, K. H. 1977. The camel as a meat and milk animal. World Anim. Rev. 22: 39-44, FAO, Rome.

Knoess, K. H., A. J. Makhudum, M. Rafiq and M. Hafeez. 1986. Milk production potential of the dromedary with special reference to the province of Punjab, Pakistan. World Anim. Rev. 57:11-21, FAO, Rome.

Mohamed, A. M. 1993. Camel (Camelus dromedarius) milk: Chemical composition and traditional preservation methods. In: The multipurpose camel: Interdisciplinary studies on pastoral production in Somalia. EPOS. Uppsala, Sweden:177-186.

Rakes, J. M. and O. T. Stallcup. 1975. Variation in composition of milk produced in Arkansas. Bull. Arkansas
Agri. Expt. Station, 802:23 (Dairy Sci.Abst.,41(2):64,1979).

Rodriguez, L. A., G. Mekonnen, C.J. Wilcox, F.G. Martin and W.A. Krienke. 1985. Effects of relative humidity, maximum and minimum temperature, pregnancy, stage of lactation on milk composition and yield. J. Dairy Sci. 68: 973.

Sawaya, W. N., J. K. Khalil, A. Al-Shalhat and H. Al-Mohammad. 1984. Chemical composition and nutritional quality of camel milk. J. Food Sci. 49:744-747.

Schwartz, H. J. 1992. Productive performance and productivity of dromedaries (Camelus dromedarius). Anim. Res. Dev. 35: 86-98.

Sokal R. R. and F. J. Rohlf. 1995. BiometryThe Principles and Practices of Statistics in Biological Research. W. H. Freeman and Company, New York, USA.

Tilakaratne, N., S. S. E. Ranawana and V. Buranendran.1975. A note on the milk composition of European cattle and their crosses with Sindhi. Ceylon Vet. J. 23(1-2):14-15 (Dairy Sci. Abst., 39(6):378,1977).

Yagil, R. 1982. Camels and camel milk. Anim. Prod. and Health Paper No. 26:1-69, FAO, Rome.

Yagil, R. and Z. Etzion. 1980 . Milk yield of camels (Camelus dromedarius) in drought areas. Comp. Biochem. Physiol. 67 A: 207-209.

Zia-ur-Rehman, I. U. Haq, E. A. Bengali, A. W. M. Jali, N. Akhtar and M. U. Khan. 1998. Influence of stage of lactation on the composition of camel milk. In: Proc. 8th World Conf. on Anim. Prod. 28 June to 04 July, Seoul National University, Seoul, Korea: 276-277. 